\title{
MANIPULOWANIE ZYSKAMI PRZEZ SPÓŁKI DEBIUTUJĄCE NA GPW
}

\section{WSTĘP}

Manipulowanie zyskami (earnings manipulation) jest zjawiskiem stanowiącym przedmiot zainteresowań zarówno praktyków, jak i środowiska naukowego. Zakres pojęciowy zarządzania zyskami w literaturze przedmiotu jest dość zróżnicowany. Na potrzeby niniejszych badań przyjęto, że „do zarządzania zyskami dochodzi wówczas, gdy menedżerowie używają swobody decyzyjnej w procesie raportowania finansowego i kształtowania transakcji, aby zmieniać zawartość sprawozdań finansowych albo w celu wprowadzenia w błąd interesariuszy firmy odnośnie do podstaw kondycji przedsiębiorstwa, albo w celu wpływu na efekty innych kontraktów, zależne od raportowanych

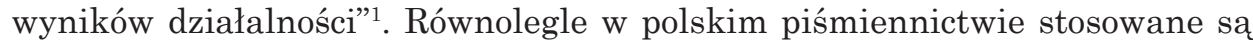
takie pojęcia, jak zarządzanie zyskami, zarządzanie wynikiem, kształtowanie zysków czy kształtowanie wyników. Działania takie nie powinny być mylone z kreatywną księgowością i preparowaniem zafałszowanych sprawozdań finansowych, choć w praktyce granica pomiędzy działaniami legalnymi i nielegalnymi może być w niektórych przypadkach trudna do zarysowania ${ }^{2}$.

Manipulowanie zyskami odnosi się do problematyki zawartości informacyjnej sprawozdawczości finansowej ${ }^{3}$. Szczegółowe przepisy prawa precyzuja, w jaki sposób określone zdarzenia gospodarcze powinny być odzwierciedlane w księgach rachunkowych, a finalnie - w sprawozdaniach finansowych. Ustawodawca dopuszcza jednak w tym zakresie pewną swobodę zarządzajacych. Ekspercka wiedza menedżerów i znajomość szczegółów transakcji z perspektywy insiderów powinny być co do zasady wykorzystywane w celu wiernego odzwierciedlenia sytuacji spółki użytkownikom sprawozdań finansowych. Pewna swoboda w zakresie kształtowania niektórych kategorii finansowych

\footnotetext{
* Badania zostały sfinansowane ze środków projektu badawczego przyznanego przez Narodowe Centrum Nauki (2015/19/D/HS4/01950).

${ }^{1}$ Definicja za: P. M. Healy, J. M. Wahlen, A review of the earnings management literature and its implications for standard setting, „Accounting Horizons” 13(4), 1999, s. 368 (tłum. J. Lizińska).

2 J. Gajdka, Kształtowanie zysków w przedsiębiorstwach w kontekście kryzysu finansowego, „Zeszyty Naukowe Uniwersytetu Szczecińskiego. Finanse. Rynki finansowe. Ubezpieczenia” 2012, nr 51, s. 303-311.

${ }^{3}$ P. Wójtowicz, Wiarygodność sprawozdań finansowych wobec aktywnego kształtowania wyniku finansowego, Wyd. UE w Krakowie, Kraków 2010, s. 7.
} 
może być jednak wykorzystywana w celu wręcz przeciwnym, skutkując nadmiernym promowaniem jednej z grup interesariuszy kosztem innych.

Specyfika zarządzania zyskami sprawia, iż outsiderom trudno jest zazwyczaj ocenić, czy sprawozdania finansowe we właściwy sposób odzwierciedlaja kondycję przedsiębiorstwa. Z oczywistych bowiem względów menedżerowie nie informuja raczej pozostałych grup interesariuszy o działaniach w obszarze manipulowania zyskami. Asymetria informacji może być w niektórych sytuacjach szczególnie nasilona, a przykładem jest pierwotna emisja akcji (initial public offering, IPO), gdyż przedmiotem transakcji są spółki bez historii właściwej spółkom publicznym. Debiutującym spółkom zazwyczaj zależy na korzystnym uplasowaniu emisji, co może skłaniać do takiego kształtowania wyników, aby zwiększyć atrakcyjność spółki. Badanie zjawiska manipulowania zyskami dla spółek wchodzących na rynek publiczny wydaje się więc ciekawe i uzasadnione.

Potrzeba badań w tym zakresie dla Giełdy Papierów Wartościowych w Warszawie (GPW) jest dodatkowo uzasadniona faktem, iż skłonność przedsiębiorstw do zarządzania zyskami może być determinowana specyficznymi rozwiązaniami na poziomie krajowym ${ }^{4}$. Pierwotne emisje akcji w Polsce były dotychczas przedmiotem zainteresowania głównie w obszarze krótko- i długookresowej reakcji cenowej po debiucie ${ }^{5}$. Zagadnienie manipulowania zyskami w momencie emisji akcji było podejmowane w badaniach prowadzonych dla zagranicznych rynków, głównie dla rynku amerykańskiego ${ }^{6}$, ale również dla rynków wschodzących? ${ }^{7}$ Zjawisko kształtowania wyników przez spółki notowane na polskim rynku kapitałowym było dotychczas przedmiotem badań empirycznych tylko kilkakrotnie, zazwyczaj w odniesieniu do wszystkich

${ }^{4}$ R. Ball, S. P. Kothari, A. Robin, The effect of international institutional factors on properties of accounting earnings, „Journal of Accounting and Economics” 29(1), 2000, s. 1-51; R. Ball, Infrastructure requirements for an economically efficient system of public financial reporting and disclosure, Brookings-Wharton papers on financial services 2001, nr (1), s. 127-169.

5 J. Lizińska, L. Czapiewski, Reassesing Polish IPO underpricing and underperformance, „Acta Universitatis Lodziensis. Folia Oeconomica” 2015, nr 1(310), s. 57-70; eidem, Determinanty underpricingu $w$ Polsce $i$ na innych wybranych rynkach wschodzacych, „Prace Naukowe Uniwersytetu Ekonomicznego (AE) we Wrocławiu” 2015, nr 386, s. 112-125; A. Cornanic, J. Novak, Signaling by underpricing the initial public offerings of primary listings in an emerging market, 2013, SSRN 2273470; J. Lizińska, L. Czapiewski, Is the IPO anomaly in Poland only apparent or real?, w: The Essence and Measurement of Organizational Efficiency, Springer International Publishing 2016, s. 175-194.

${ }^{6}$ Przykładowo: J. Aharony, C. J. Lin, M. P. Loeb, Initial Public Offerings, accounting choices, and earnings management, „Contemporary Accounting Research” 10(1), 1993, s. 61-81; R. Ball, L. Shivakumar, Earnings quality at initial public offerings, „Journal of Accounting and Economics” 45(2), 2008, s. 324-349; L. L. DuCharme, P. H. Malatesta, S. E. Sefcik, Earnings management: IPO valuation and subsequent performance, „Journal of Accounting, Auditing \& Finance” 16(4), 2001, s. 369-396; J. M. Friedlan, Accounting choices of issuers of Initial Public Offerings, „Contemporary Accounting Research” 11(1), 1994, s. 1-31; S. H. Teoh, I. Welch, T. J. Wong, Earnings management and the long-run market performance of initial public offering, „Journal of Finance” 53(6), 1998, s. 1935-1974.

7 Przykładowo: N. A. Ahmad-Zaluki, K. Campbell, A. Goodacre, Earnings management in Malaysian IPOs: The East Asian crisis, ownership control, and post-IPO performance, „International Journal of Accounting" 46(2), 2011, s. 111-137. 
polskich spółek ${ }^{8}$. Autorom znane jest tylko jedno opracowanie z szerokiego obszaru dotykającego problematyki zawartości informacyjnej sprawozdań finansowych i odnoszace się jednocześnie do pierwszych publicznych emisji ${ }^{9}$. Zaprezentowane tam badania empiryczne - choć interesujace i ambitne - stawiały analizowane zjawisko w innym ujęciu do tego, jakie jest przedmiotem badań w niniejszym artykule, gdyż praca w bezpośredni sposób odnosiła się do ryzyka informacyjnego.

Celem badań empirycznych, których wyniki przedstawia niniejsze opracowanie, była odpowiedź na pytanie, czy dla spółek dokonujących pierwotnych emisji akcji w Polsce zaobserwować można zjawisko zarządzania zyskami w okresach okołoemisyjnych. Badania prowadzone były dla spółek z sektora pozafinansowego debiutujących na Giełdzie Papierów Wartościowych w Warszawie w latach 1998-2013.

\section{PROBLEM WYBORU METODY BADANIA ZJAWISKA MANIPULOWANIA ZYSKAMI}

W procesie empirycznej identyfikacji zjawiska manipulowania zyskami stosowane sa zazwyczaj dwa główne podejścia zmierzające do wykrycia działań o charakterze realnym oraz memoriałowym. Działania o charakterze realnym (real activities manipulation) sa podejmowane w celu zmiany raportowanych zysków w określonym kierunku, co następuje przez modyfikację momentu wystapienia bądź konstrukcji transakcji o charakterze operacyjnym, inwestycyjnym czy finansowym i skutkuja nieefektywnymi konsekwencjami dla spółki ${ }^{10}$. W związku z tym wpływają na rzeczywiste transakcje realizowane przez przedsiębiorstwo. Przykładem może być redukcja wydatków na badania i rozwój czy reklamę w określonych okresach albo odkładanie w czasie wdrażania nowych projektów. Co prawda kształtowanie wyniku typu realnego było przedmiotem badań empirycznych prowadzonych dla rozwiniętych rynków, ale jednak - z uwagi na istotną lukę informacyjną dla debiutujących spółek niepopularnych w powiązaniu z obszarem $\mathrm{IPO}^{11}$.

\footnotetext{
${ }^{8}$ Przykładowo: J. Gajdka, op. cit., s. 303-311; P. Wójtowicz, op. cit.; idem, Earnings management to achieve positive earnings surprises in case of medium size companies listed in Poland, „International Journal of Accounting and Economics Studies" 3(2), 2015, s. 141-147; J. M. Wyrobek, Z. Stanczyk, Kreowanie obrazu przedsiębiorstw w polskiej rachunkowości, 2013, SSRN 2290587 (01.02.2016); P. Czajor, J. Michalak, H. Waniak-Michalak, Influence of economy growth on earnings quality of listed companies in Poland, „Social Sciences” 82(4), 2014, s. 48-58.

${ }_{9}^{9} \mathrm{~J}$. Truszkowski, Wptyw ryzyka informacyjnego na długookresowe stopy zwrotu z akcji po pierwszych publicznych emisjach, 2013, prace doktorskie Uniwersytetu Ekonomicznego w Poznaniu.

${ }^{10}$ Definicja za: A. Y. Zang, Evidence on the trade-off between real activities manipulation and accrual-based earnings management, „Accounting Review” 87(2), 2011, s. 675-703 (tłum. J. Lizińska).

${ }^{11}$ Badania dotyczyły specyficznych transakcji IPO, przykładowo: W. Wongsunwai, op. cit, s. 296-324. W szerszym kontekście prowadzono dla działań realnych badania raczej dla kolejnych emisji akcji (seasoned equity offerings), przykładowo: D. Cohen, P. Zarowin, Accrual-based and
} 
W niniejszym opracowaniu zastosowane zostało drugie z wymienionych podejść. Zmierza ono do wykrycia manipulowania wynikami przez działania o charakterze memoriałowym i odbywa się przez wpływanie na księgowe ujęcie transakcji ${ }^{12}$ (accrual-based earnings management). Przykładem może być wybór metody amortyzacji czy zmiana wyceny wątpliwych należności. Dotychczasowe badania nad emisjami akcji prowadzone dla zagranicznych rynków koncentrowały się właśnie na tym podejściu.

Charakter zjawiska manipulowania zyskami sprawia, że bezpośrednie jego zbadanie nie jest najczęściej możliwe. Badania empiryczne wymagają zastosowania pewnych miar pośrednich (proxy). Jednym ze sposobów identyfikacji zjawiska manipulowania zyskami jest analiza skłonności do przekraczania wartości progowych (thresholds). Takie wartości progowe zdają się mieć szczególne znaczenie ekonomiczne i psychologiczne dla interesariuszy spółki ${ }^{13}$. W niniejszych badaniach badano skłonność do wykazywania wyniku finansowego na poziomie zerowym oraz równym zyskowi z poprzedniego okresu.

Druga, bardzo szeroka grupa metod identyfikacji zjawiska manipulowania zyskami polega na szacowaniu przesunięć międzyokresowych. Zasadniczo na zyski przedsiębiorstwa składają się przepływy operacyjne oraz odpowiednie korekty sprawiajace, że zyski księgowe nie są w danym okresie sprawozdawczym równe przepływom środków pieniężnych. Te korekty, czy inaczej przesunięcia międzyokresowe (accruals, ACC), mogą mieć dwojaki charakter. Do dokonywania niektórych przedsiębiorstwo jest zobowiązane (wynikają z rodzaju prowadzonej działalności lub są konsekwencją zmian w otoczeniu przedsiębiorstwa), a menedżerowie nie mają wpływu na ich wielkość czy przypisanie do danego okresu sprawozdawczego (tzw. typowe przesunięcia międzyokresowe, non-discretionary accruals, NDACC). Inne przesunięcia kosztów bądź przychodów między okresami sprawozdawczymi moga mieć charakter fakultatywny (discretionary accruals, DACC). Jednakże sam fakt wystapienia korekt różnicujących poziom przepływów i zysków jest tylko punktem wyjścia do potwierdzenia występowania zjawiska manipulowania zyskami, gdyż pewne korekty nie powinny być przypisywane celowym zabiegom kształtowania wyniku. Największym wyzwaniem - szczególnie dla spółek dopiero wchodzących na giełdę - jest oszacowanie poziomu ponadnormalnych korekt.

Jeden z relatywnie prostszych sposobów szacowania nietypowych przesunięć międzyokresowych bazuje na założeniu, że pewnym proxy dla zysków, jakie byłyby odnotowane w sytuacji, gdyby do zarządzania zyskami nie dochodziło, będą stanowiły przepływy ${ }^{14}$. Menedżerom zdecydowanie łatwiej jest

real earnings management activities around seasoned equity offerings, „Journal of Accounting and Economics" 50(1), 2010, s. 2-19.

12 Definicja za: A. Y. Zang, op. cit., s. 675-703 (tłum. J. Lizińska).

${ }^{13}$ Badania w tym zakresie prowadzili m.in. D. Burgstahler, I. Dichev, Earnings management to avoid earnings decreases and losses, „Journal of Accounting and Economics” 24(1), 1997, s. 99126, czy F. Degeorge, J. Patel, R. Zeckhauser, Earnings management to exceed thresholds, „Journal of Business" 72(1), 1999, s. 1-33.

${ }^{14}$ P. M. Healy, The effect of bonus schemes on accounting decisions, „Journal of Accounting and Economics" 7(1), 1985, s. 85-107; idem, The impact of bonus schemes on accounting choices, Dissertation 1983 University of Rochester, Rochester, NY, http://dspace.mit.edu/bitstream/handle/1721.1/48190/ impactofbonussch00heal.pdf?sequence=1\&origin=publication_detail [dostęp: 15.01.2016]. 
dokonywać przesunięć międzyokresowych w zakresie kategorii kształtujących zysk (przychodów, kosztów), a zdecydowanie trudniej transferować między okresami sprawozdawczymi przepływy środków pieniężnych. Wyróżnienie korekt typowych i nietypowych jest możliwe dzięki aplikacji modelu DeAngelo ${ }^{15}$. Przyjęto w nim pewną modyfikację modelu Healy ${ }^{16}$ polegającą na tym, że typowe przesunięcia szacowane są na podstawie jednego okresu.

Estymacja poziomu typowych przesunięć międzyokresowych za pomoca modelu DeAngelo będzie poprawna do momentu, gdy korekty typowe pozostaja niezmienne $\mathrm{w}$ czasie $^{17}$. Możliwe jest jednak, że to zmiana warunków ekonomicznych (a nie oportunistyczna chęć kształtowania wyniku) wymusza na przedsiębiorstwie zmiany poziomu przesunięć międzyokresowych. Kamieniem milowym w pracach empirycznych nad manipulowaniem zyskami była praca Jennifer Jones z 1991 r. W niniejszych badaniach dokonano aplikacji zaproponowanego tam modelu, wydzielając korekty będące efektem zwykłej działalności przedsiębiorstwa oraz przesunięcia nietypowe ${ }^{18}$.

Model Jones w wersji podstawowej może w niektórych przypadkach niedoszacowywać korekty nietypowe, jeżeli zarządzanie wynikiem następuje droga przesunięć w czasie pozycji przychodów. Dodatkowo zastosowano więc model Jones $\mathrm{w}$ wersji zmodyfikowanej o należności ${ }^{19}$. Wówczas nietypowe zmiany w sprzedaży kredytowej przypisane będa zjawisku manipulowania zyskami przez dane przedsiębiorstwo.

W niniejszych badaniach do identyfikacji zjawiska zarządzania zyskami zastosowano również pomocniczo procedurę zaproponowaną przez François Degeorge'a i in. ${ }^{20}$, bazującą na obserwacji zmian rentowności w wyróżnionych grupach spółek.

\section{III. ŹRÓDŁA DANYCH I SZCZEGÓŁOWE PROBLEMY BADAWCZE}

Przedmiotem badań były pierwotne emisje akcji dokonywane przez spółki z sektorów pozafinansowych na rynku głównym Giełdy Papierów Wartościowych w Warszawie (GPW) w latach 1998-2013. Brano pod uwagę tylko te debiuty giełdowe, które wiązały się z nową ofertą akcji ${ }^{21}$. W badaniach korzy-

15 L. E. DeAngelo, Accounting numbers as market valuation substitutes: A study of management buyouts of public stockholders, „Accounting Review” 1986, s. 400-420.

${ }_{16}$ P. M. Healy, The effect..., s. 85-107.

${ }_{17}$ P. M. Dechow, R. G. Sloan, A. P. Sweeney, Detecting earnings management, „Accounting Review" 1995, s. 193-225.

18 J. J. Jones, Earnings management during import relief investigations, „Journal of Accounting Research" 1991, s. 193-228.

19 P. M. Dechow, R. G. Sloan, A. P. Sweeney, op. cit., s. 193-225.

${ }^{20}$ Metoda zaczerpnięta z: F. Degeorge, J. Patel, R. Zeckhauser, op. cit., s. 1-33. W Polsce stosowana dla ogółu spółek (nie IPO) przez: J. Brzeszczyński, J. Gajdka, T. Schabek, Earnings management in Polish companies, „Comparative Economic Research” 2011, nr 14(3), s. 137-150.

21 Spółki z sektora finansowego zostały wyłączone ze względu na odmienny charakter sprawozdań finansowych. Z uwagi na odmienny charakter obowiązków informacyjnych wyłączono również spółki z rynku alternatywnego New Connect. Badaniem wyłącznie debiuty klasycznej 
stano ze wsparcia Microsoft Excel z aplikacją Visual Basic for Applications. Testy statystyczne zostały przeprowadzone $\mathrm{z}$ wykorzystaniem platformy oprogramowania R.

Źródłem badań były Notoria Serwis, oficjalna strona GPW (www.gpw.pl) oraz www.gpwinfostrefa.pl. Z uwagi na niedoskonałości istniejących baz danych w zakresie zawartości sprawozdań finansowych (błędy, brak danych dla spółek obecnie niekwotowanych), na podstawie danych pierwotnych stworzona została własna baza danych.

Postawiono cztery szczegółowe grupy problemów badawczych dotyczące: skłonności do przekraczania zysku zerowego, skłonności do przekraczania zysku roku poprzedniego, manipulowania zyskami przez dokonywanie nietypowych przesunięć międzyokresowych oraz konsekwencji manipulowania zyskami dla kolejnych okresów sprawozdawczych.

Jeżeli debiutujące spółki dążyły do zwiększenia zysku w okresie okołoemisyjnym, czego wyrazem będzie nasilenie skłonności do przekraczania wartości progowej w postaci dodatniego zysku, to $\mathrm{w}$ roku emisji (względnie w okresie bezpośrednio przed IPO) oczekiwane jest zwiększenie liczby firm wykazujących małe zyski w relacji do firm raportujących małe straty. Dodatkowo, z uwagi na charakter przesunięć międzyokresowych, w okresie następującym bezpośrednio po debiucie oczekiwane jest odwrócenie relacji.

Jeżeli debiutujące spółki dążyły do zwiększenia zysku w okresie okołoemisyjnym, czego wyrazem będzie nasilenie skłonności do przekraczania wartości progowej w postaci zysku roku poprzedniego, to w roku emisji (względnie w okresie bezpośrednio przed IPO) oczekiwana jest relatywnie wysoka przeciętna dynamika zysku. W konsekwencji takich korzystnych wizerunkowo przesunięć międzyokresowych spodziewać się należy, że w okresie następującym po debiucie przeciętna dynamika zmian rentowności będzie ulegała relatywnemu pogorszeniu.

Jeżeli debiutujące spółki dążyły do zwiększenia zysku w okresie okołoemisyjnym, to dla spółek najbardziej podejrzewanych o dokonywanie tego typu działań w roku debiutu powinien zostać zaobserwowany relatywny spadek rentowności w okresie po debiucie.

Jeżeli debiutujące spółki dążyły do zwiększenia zysku w okresie okołoemisyjnym przez działania typu memoriałowego, to w roku emisji (względnie w okresie bezpośrednio przed IPO) przeciętny poziom nietypowych przesunięć międzyokresowych powinien być relatywnie wysoki i dodatni. Konsekwencja dokonywania takich korekt w celu poprawy wizerunku przedsiębiorstwa i korzystnego uplasowania emisji powinien być relatywny spadek przeciętnego poziomu nietypowych korekt $\mathrm{w}$ okresie bezpośrednio po emisji.

postaci, związane z pozyskaniem kapitału. Okres badawczy został ustalony na podstawie oceny dostępności i kompletności sprawozdań finansowych oraz liczby notowanych spółek, co miało związek z przyjętą metodą badawczą i koniecznością budowania portfeli benchmarkowych na podstawie danych finansowych. 


\section{SKŁONNOŚĆ DO WYKAZYWANIA MAŁYCH ZYSKÓW I STRAT}

Wstępnej oceny zjawiska kształtowania wyniku w okresach okołoemisyjnych dokonano na podstawie rozkładu wskaźników rentowności sprzedaży (wykres 1). O ile w roku debiutu (Y0) aż 65\% przedsiębiorstw raportowało pozytywną rentowność sprzedaży, o tyle w roku po IPO $(Y+1)$ było to jedynie $56 \%$. W roku debiutu tylko 5\% przedsiębiorstw wykazywało negatywną rentowność sprzedaży, a rok po debiucie było ich aż 19\%. Wyniki sugerują negatywne konsekwencje zarządzania zyskami w okresie debiutu dla rentowności w latach kolejnych.

\section{Wykres 1}

Histogram dla rentowności sprzedaży w okolicach debiutu

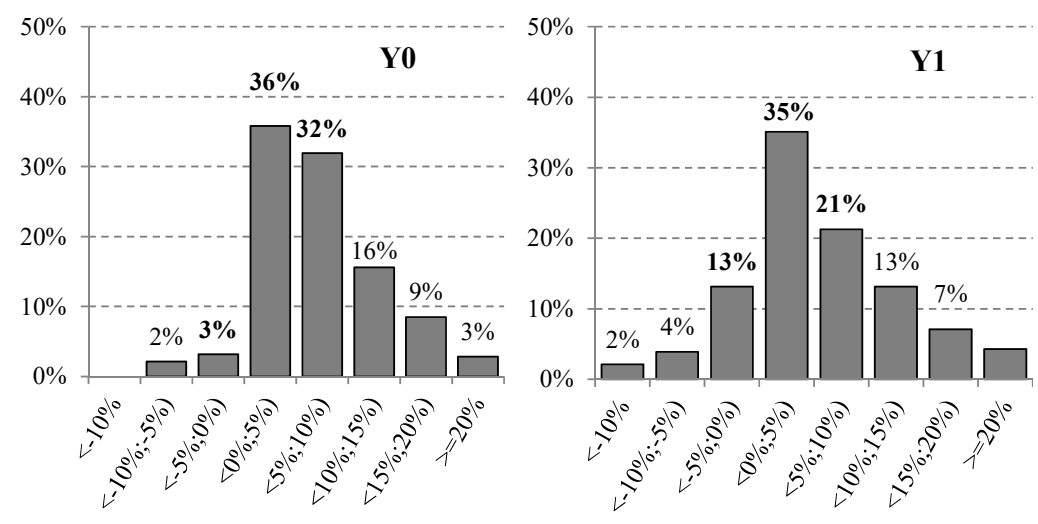

Źródło: opracowanie własne.

W celu bezpośredniego przeanalizowania skłonności przedsiębiorstw do wykazywania nieujemnego wyniku finansowego posłużono się wzorem:

$$
M Z M S=\frac{N_{M Z}}{N_{M S}}
$$

gdzie:

$N_{M Z}, N_{M S} \quad$ liczba przedsiębiorstw osiagających odpowiednio małe zyski/ małe straty na podstawie danego wskaźnika.

Specyfika transakcji IPO owocuje m.in. tym, że w roku emisji następuje zmiana liczby akcji oraz wartości księgowej majątku. W związku z tym zrezygnowano z wyboru na wskaźnik bazowy do miary MZMS wskaźnika rentowności aktywów, wskaźnika rentowności kapitałów własnych czy wskaźnika zysków na akcję. Zamiast tego posłużono się wskaźnikiem dynamiki zmian zysku netto $(\% \Delta N I)$ oraz wskaźnikiem rentowności sprzedaży $(R O S)$. Spółka była klasyfikowana jako osiagająca „małe zyski”, jeżeli wskaźnik dynamiki zysku netto 
oraz rentowności sprzedaży znajdowały się w przedziale odpowiednio $(0 ; 0,1)$ i $(0 ; 0,02)$, a „małe straty”, gdy wskaźniki znajdowały się w przedziale odpowiednio $(-0,01 ; 0)$ i $(-0,02 ; 0)$.

Przypadki odstające poddano procedurze eliminacji, gdzie dolna i górna granica przedziału ustalona została na podstawie odstępu międzykwartylowego $(I Q R)$ jako odpowiednio $Q_{1}-1,5 \cdot I Q R$ i $Q_{3}+1,5 \cdot I Q R$, gdzie $Q_{1}$ i $Q_{3}$ to odpowiednio wartości kwartyla pierwszego i trzeciego dla danej cechy.

Tabela 1

Wskaźnik małych zysków i małych strat

\begin{tabular}{|l|c|c|c|c|c|c|c|}
\hline \multicolumn{2}{|r|}{ Y-2 } & Y-1 & Y0 & Y+1 & Y+2 & Y+3 & Y+4 \\
\hline \multicolumn{7}{|l|}{ Panel A: Zmiana zysku netto } \\
\hline MZ/MS & 2,25 & 1,86 & 2,30 & 0,83 & 1,71 & 1,18 & 1,31 \\
\hline N & 195 & 212 & 271 & 279 & 256 & 240 & 213 \\
\hline Panel B: Rentownośćc sprzedaży \\
\hline MZ/MS & 11,20 & 11,67 & 6,80 & 3,00 & 2,45 & 2,45 & 5,40 \\
\hline N & 232 & 278 & 282 & 282 & 259 & 254 & 212 \\
\hline
\end{tabular}

Źródło: opracowanie własne.

Dane zawarte w tabeli 1 wskazuja, że w roku debiutu liczba firm wykazujaccych małe zyski w relacji do firm raportujaccych małe straty była relatywnie wysoka. Przy zastosowaniu wskaźnika zmiany zysku netto zaobserwowano w roku emisji najwyższą wartość wskaźnika w zestawieniu z wartościami raportowanymi dla pozostałych sześciu lat okołoemisyjnych. Aplikacja wskaźnika rentowności sprzedaży również pozwoliła zaobserwować w roku $Y 0$ emisji wysoką wartość wskaźnika (a najwyższą w latach bezpośrednio poprzedzających $Y-1$ oraz $Y-2$ ). W latach poemisyjnych następował silny spadek wartości tego wskaźnika.

Wyniki stanowią przesłankę do uznania, iż spółki debiutujące na GPW charakteryzowały się większą skłonnością do przekraczania wartości progowej w postaci zerowego zysku w roku debiutu lub tuż przed debiutem. W konsekwencji jednak w latach następujących bezpośrednio po debiucie obserwowano załamanie - negatywne konsekwencje dla rentowności.

\section{SKŁONNOŚĆ DO PRZEKRACZANIA RENTOWNOŚCI ROKU POPRZEDNIEGO}

Istotną informacją dla inwestorów może być również tempo zmian zysku $\mathrm{w}$ stosunku do poprzedniego okresu. Z uwagi na opisane wcześniej zmiany w sprawozdaniach finansowych powodowane specyfiką IPO ponownie przyjęto miary rentowności w postaci wskaźnika dynamiki zmian zysku netto $(\% \Delta \mathrm{NI})$ oraz zmian wskaźnika rentowności sprzedaży (\% $\%$ ROS). Przypadki odstające poddano procedurze eliminacji. 
Tabela 2

Skłonność do przekraczania zerowego tempa zmian rentowności

\begin{tabular}{|l|c|c|c|c|c|c|c|c|}
\hline \multicolumn{2}{|c|}{ Y-2 } & Y-1 & Y0 & $Y+1$ & $Y+2$ & $Y+3$ & $Y+4$ \\
\hline Panel A: Procentowa zmiana zysku netto \\
\hline Średnia & $58,6 \%$ & $62,9 \%$ & $28,5 \%$ & $-8,3 \%$ & $-10,5 \%$ & $7,3 \%$ & $32,3 \%$ \\
\hline Mediana & $36,7 \%$ & $37,7 \%$ & $26,4 \%$ & $-4,0 \%$ & $3,5 \%$ & $5,9 \%$ & $21,4 \%$ \\
\hline$\%>0$ & $69 \%$ & $78 \%$ & $73 \%$ & $50 \%$ & $52 \%$ & $55 \%$ & $63 \%$ \\
\hline$\%<0$ & $31 \%$ & $22 \%$ & $27 \%$ & $50 \%$ & $48 \%$ & $45 \%$ & $37 \%$ \\
\hline N & 202 & 220 & 266 & 282 & 259 & 244 & 213 \\
\hline Panel B: Procentowa zmiana rentowności sprzedaży & & & \\
\hline Średnia & $33,8 \%$ & $32,7 \%$ & $2,6 \%$ & $-23,1 \%$ & $-15,7 \%$ & $-3,5 \%$ & $21,9 \%$ \\
\hline Mediana & $11,4 \%$ & $13,9 \%$ & $3,1 \%$ & $-18,5 \%$ & $-9,6 \%$ & $-3,9 \%$ & $9,7 \%$ \\
\hline$\%>0$ & $60 \%$ & $66 \%$ & $55 \%$ & $34 \%$ & $42 \%$ & $48 \%$ & $57 \%$ \\
\hline$\%<0$ & $40 \%$ & $34 \%$ & $45 \%$ & $66 \%$ & $58 \%$ & $52 \%$ & $43 \%$ \\
\hline N & 203 & 221 & 269 & 276 & 255 & 231 & 215 \\
\hline
\end{tabular}

Źródło: opracowanie własne.

W roku debiutu odsetek spółek wykazujacych wzrost zysku netto był wysoki (choć najwyższy odnotowany został rok przed debiutem). Aż 73\% debiutujących spółek wykazało wzrost zysku netto w roku debiutu (78\% w roku przed debiutem), podczas gdy w latach po wejściu na giełdę pozytywną dynamikę wyniku finansowego wykazywało nieco ponad 50\% wcześniejszych debiutantów. O ile w roku debiutu średni przyrost zysku netto wynosił średnio $28,5 \%$ (przy medianie 26,4\%), o tyle w latach następujących po emisji średnia dynamika zmian zysku była zdecydowanie mniej korzystna - w roku bezpośrednio po emisji zyski przeciętnie malały w stosunku do roku poprzedniego.

Podobne kierunki zmian występowały dla wskaźnika rentowności sprzedaży. W roku IPO aż 55\% spółek odnotowało wzrost rentowności sprzedaży, a w roku po emisji aż 66\% debiutantów odnotowało spadek rentowności sprzedaży w porównaniu z rokiem poprzednim. Dynamika rentowności sprzedaży była w roku emisji pozytywna, ale niższa niż w dwóch latach przed emisją. Przeciętne zmiany rentowności sprzedaży w okresie kolejnych trzech lat po pierwotnej emisji akcji są negatywne - spółki nie osiagały w tym okresie rentowności nawet na poziomie roku poprzedniego.

Wyniki te potwierdzaja, iż w roku dokonania IPO (ale i w latach bezpośrednio przed debiutem) zaobserwowano nasilenie skłonności do przekraczania wartości progowej w postaci zysku roku poprzedniego i rentowności sprzedaży na poziomie roku poprzedniego. W konsekwencji w kolejnych latach debiutanci odnotowywali w okresie po emisji spadki (lub przynajmniej mniej spektakularne wzrosty) zysku netto i rentowności sprzedaży. 


\section{KONSEKWENCJE ZARZĄDZANIA ZYSKAMI W OKRESACH OKOŁOEMISYJNYCH W KONTEKŚCIE PRZYSZŁEJ RENTOWNOŚCI}

Posługując się procedura zaproponowaną przez F. Degeorge i in. ${ }^{22}$, debiutujące spółki zostały podzielone na grupy w zależności od poziomu wskaźnika rentowności w roku IPO. Chociaż metoda ta nie jest metodą umożliwiająca testowanie istotności statystycznej hipotez formułowanych $\mathrm{w}$ odniesieniu do zjawiska manipulowania zyskami, to jednak jej zaleta jest to, że w dość obrazowy sposób pozwala na analizę konsekwencji praktyk manipulowania zyskami w okresach okołoemisyjnych. Użyto miary pomocniczej:

gdzie:

$$
\mathrm{k}=2 \cdot I Q R \cdot n^{(-1 / 3)},
$$

$I Q R$ odstęp międzykwartylowy dla przyjętego wskaźnika rentowności (PR),

$n \quad$ liczba obserwacji.

W konsekwencji wyróżniono pięć grup spółek według kryteriów opisanych w tabeli 3.

Tabela 3

Kryteria podziału spółek na grupy względem rentowności

\begin{tabular}{|c|l|c|}
\hline Nazwa & \multicolumn{1}{|c|}{ Kryteria } & Cecha \\
\hline A & Rentowność poniżej wartości progowej & $P R<-k$ \\
\hline B & Rentowność nieznacznie poniżej wartości progowej & $-k \leq P R<0$ \\
\hline C & Rentowność nieznacznie powyżej wartości progowej & $0 \leq P R<k$ \\
\hline D & Rentowność znacznie powyżej wartości progowej & $k \leq P R<2 k$ \\
\hline E & Rentowność zdecydowanie powyżej wartości progowej & $P R>2 k$ \\
\hline
\end{tabular}

Źródło: opracowanie własne.

Przeciętną rentowność spółek należących do każdej z grup (A, B, C, D, E) oznaczono jako $a_{t}, b_{t}, c_{t}, d_{t}, e_{t}$. W konsekwencji w roku IPO dla parametrów zachodzi relacja:

$$
a_{Y O}<b_{Y O}<c_{Y O}<d_{Y O}<e_{Y 0^{\circ}}
$$

Gdyby praktyki manipulowania zyskami w roku debiutu nie miały miejsca i nie zostałyby wówczas dokonywane ponadnormalne przesunięcia międzyokresowe skutkujące okresowym tylko wzrostem rentowności, wówczas również w roku kolejnym $(Y+1)$ powinna zachodzić podobna relacja, a w szczególności:

$$
b_{Y+1}<c_{Y+1}<d_{Y+1} .
$$

${ }^{22}$ Metoda zaczerpnięta z: F. Degeorge, J. Patel, R. Zeckhauser, op. cit., s. 1-33. W Polsce stosowana dla ogółu spółek (nie IPO) przez: J. Brzeszczyński, J. Gajdka, T. Schabek, op. cit., s. $137-150$. 
Obliczono wartości wskaźnika rentowności sprzedaży dla spółek notowanych na GPW w okresie 1998-2013. Przypadki odstajace poddano opisanej wyżej procedurze eliminacji. Następnie obliczono wartości miary pomocniczej i na jej podstawie określona została przynależność debiutujących spółek do grupy A, B, C, D oraz E, przyjmując, iż rokiem klasyfikacji będzie rok debiutu (YO). Wyniki obliczeń przedstawiono w tabeli 4.

Tabela 4

Rentowność sprzedaży dla grup spółek

\begin{tabular}{|l|c|c|c|c|c|c|}
\hline \multirow{2}{*}{ Grupy spółek: } & \multicolumn{3}{|c|}{ Y0 } & \multicolumn{3}{c|}{ Y+1 } \\
\cline { 2 - 6 } & Średnia & Mediana & $\boldsymbol{N}$ & Średnia & Mediana & $\boldsymbol{N}$ \\
\hline a & $-4,0 \%$ & $-5,0 \%$ & 9 & $-5,0 \%$ & $-3,0 \%$ & 13 \\
\hline b & $-2,0 \%$ & $-2,0 \%$ & 6 & $8,0 \%$ & $10,0 \%$ & 3 \\
\hline c & $3,0 \%$ & $2,0 \%$ & 36 & $2,0 \%$ & $1,0 \%$ & 33 \\
\hline d & $6,0 \%$ & $5,0 \%$ & 59 & $3,0 \%$ & $3,0 \%$ & 57 \\
\hline e & $9,0 \%$ & $8,0 \%$ & 171 & $7,0 \%$ & $6,0 \%$ & 174 \\
\hline c-b & $5,8 \%$ & $4,3 \%$ & & $-5,9 \%$ & $-9,1 \%$ & \\
\cline { 1 - 2 } d-c & $2,6 \%$ & $2,9 \%$ & & $0,4 \%$ & $1,6 \%$ & \\
\cline { 1 - 2 } (ct-bt)<(dt-ct) & nie & nie & & tak & tak & \\
\hline
\end{tabular}

Źródło: opracowanie własne.

W roku po debiucie giełdowym nastapił relatywny spadek rentowności dla grupy spółek najbardziej podejrzewanych o dokonywanie działań z zakresu kształtowania wyniku (grupa C). Przejawem zjawiska zawyżania rentowności w roku debiutu było zaobserwowanie dla roku po IPO relacji:

$$
d_{Y+1}-c_{Y+1}>c_{Y+1}-b_{Y+1} \text { oraz } b_{Y+1}>c_{Y+1} \text {. }
$$

Dla spółek dokonujących działań z zakresu zawyżania zysku w roku debiutu zaobserwowano relatywny spadek rentowności w roku kolejnym również przy zastosowaniu metody zaproponowanej przez F. Degeorge'a i in.

\section{POZIOM ACCRUALS}

Zasadnicza część oceny zjawiska manipulowania zyskami w okresach okołoemisyjnych oparta została na obserwacji poziomu przesunięć międzyokresowych. Poziom tychże korekt (korekt łącznych) dla spółki w roku wyznaczono na podstawie wzoru:

$$
A C C_{i t}=N D A C C_{i t}+D A C C_{i t}
$$


gdzie:

$A C C_{i t} \quad$ łączna wartość przesunięć międzyokresowych dla spółki $i$ w roku $t$ skalowanych aktywami;

$N D A C C_{i t} \quad$ typowe przesunięcia międzyokresowe dla spółki $i$ w roku $t$ skalowane aktywami;

$D A C C_{i t} \quad$ nietypowe przesunięcia międzyokresowe dla spółki $i \mathrm{w}$ roku $t$ skalowane aktywami.

W pierwszym kroku szacowano najpierw korekty typowe, wykorzystując model DeAngelo, model Jones oraz zmodyfikowany model Jones.

Korekty typowe w modelu DeAngelo wyznaczone zostały przez:

$$
N D A C C_{i t}^{D}=A C C_{i t-1}
$$

Korekty typowe w modelu Jones oszacowano jako:

$$
N D A C C_{i t}^{J}=\alpha_{i 1}\left(\frac{1}{A_{i t-1}}\right)+\alpha_{i 2}\left(\Delta R E V_{i t}\right)+\alpha_{i 3}\left(P P E_{i t}\right)
$$

gdzie:

$A_{i t-1}$

wartość aktywów ogółem dla spółki z początku okresu sprawozdawczego;

$\triangle R E V_{i t} \quad$ wartość przychodów dla spółki $i$ w roku $t$ pomniejszona o przychody z roku $t-1$ skalowana aktywami;

$P P E_{i t} \quad$ wartość aktywów trwałych brutto w roku $t$ dla spółki $i$ skalowana aktywami;

$\alpha_{i 1}, \alpha_{i 2}, \alpha_{i 3}$ parametry specyficzne dla przedsiębiorstwa.

Estymacja parametrów $a_{i 1}, a_{i 2}, a_{i 3}$, dla każdej spółki $i$ w roku $t$ w oknie estymacji następowała z użyciem modelu:

$$
N D A C C_{i t}^{J}=a_{i 1}\left(\frac{1}{A_{i t-1}}\right)+a_{i 2}\left(\Delta R E V_{i t}\right)+a_{i 3}\left(P P E_{i t}\right)+\vartheta_{i t}
$$

gdzie $a_{i 1}, a_{i 2}, a_{i 3}$ to szacunkowe wartości $\alpha_{i 1}, \alpha_{i 2}, \alpha_{i 3}$ wyznaczone za pomoca metody najmniejszych kwadratów.

Typowe przesunięcia międzyokresowe w zmodyfikowanym modelu Jones oszacowano jako:

$$
N D A C C_{i t}^{M J}=\alpha_{i 1}\left(\frac{1}{A_{i t-1}}\right)+\alpha_{i 2}\left(\Delta R E V_{i t}-\Delta R E C_{i t}\right)+\alpha_{i 3}\left(P P E_{i t}\right),
$$

gdzie:

$\triangle R E C_{i t} \quad$ wartość należności dla spółki $i$ w roku $t$ pomniejszona o należności z roku $t-1$ skalowana aktywami.

Rzeczywiste przesunięcia międzyokresowe obliczone zostały na podstawie zmian pozycji bilansu. W celu ograniczenia problemu heteroskedastyczności, wartości rzeczywistych przesunięć międzyokresowych i wartości przesunięć 
estymowanych skalowano opóźnionymi aktywami ${ }^{23}$. Wartość rzeczywistych korekt obliczono jako zmianę w niepieniężnym kapitale obrotowym netto z wyłączeniem amortyzacji ${ }^{24}$.

Badania zostały przeprowadzone dla tych debiutujacych spółek z sektora pozafinansowego, które posiadały komplet danych do obliczenia poziomu rzeczywistych przesunięć, a więc takich, dla których istniały informacje o poziomie aktywów bieżących, zobowiązań bieżących, środków pieniężnych, aktywów ogółem w danym roku oraz roku poprzedzającym $t-1$ oraz amortyzacji $\mathrm{w}$ danym roku. Warunkiem szacowania poziomu korekt typowych była możliwość obliczenia korekt rzeczywistych.

W celu dekompozycji łącznych korekt posłużono się międzysektorową (cross-industry) ${ }^{25}$ wersja modelu Jones i zmodyfikowanego modelu Jones ${ }^{26}$; dotychczas aplikowali ja m.in. M. L. DeFond i J. Jiambalvo ${ }^{27}$ oraz K. R. Subramanyam oraz L. L. DuCharme, P. H. Malatesta, S. E. Sefcik ${ }^{28}$. W tym celu określono przynależność sektorową spółek notowanych na GPW. Dodatkowym warunkiem szacowania parametrów regresji było istnienie - poza daną spółką - przynajmniej pięciu spółek w tym samym sektorze. Ponadto nałożona została dwuletnia karencja na debiutujace spółki w zakresie wejścia do sektora benchmarkowego dla innego przypadku IPO.

Wartość relatywnych ponadnormalnych przesunięć międzyokresowych dla każdej debiutującej spółki oszacowano dla roku emisji ( $Y 0)$ oraz dla lat bezpośrednio poprzedzających $(Y-1$ oraz $Y-2)$, a także dla lat następujących bezpośrednio po debiucie $(Y+1, Y+2, Y+3, Y+4)$.

Przypadki odstające poddano opisanej wyżej procedurze eliminacji. Normalność rozkładu sprawdzono testem Shapiro-Wilka. Istotność statystyczna miar przeciętnych poziomu korekt testowano testem parametrycznym $t$-Studenta oraz testem nieparametrycznym znakowanych rang Wilcoxona dla jednej próby.

Rezultaty zastosowania modelu DeAngelo, modelu Jones oraz zmodyfikowanego modelu Jones zawarte zostały w tabelach 5 i 6 . Wykazane zostały istotne statystycznie przeciętne przesunięcia międzyokresowe typu DACC na poziomie świadczącym o zawyżaniu wyniku finansowego w roku IPO, przy równoległym relatywnym spadku poziomu nietypowych korekt w kolejnych okresach (generalnie najsilniejszym w pierwszym roku po emisji). Wyniki wskazuja, że debiutujące spółki dążyły w roku debiutu poprzez działania typu memoriałowego do relatywnego zwiększenia wyniku finansowego.

${ }^{23}$ J. Ronen, V. Yaari, Earnings management, Springer US, 2008, s. 405.

${ }^{24}$ J. J. Jones, op. cit., s. 193-228.

${ }^{25}$ Wersja typu time-series nie była możliwa do zastosowania z uwagi na fakt, iż badania były prowadzone dla spółek wchodzących na rynek publiczny i dla wielu z nich nie było możliwości dostępu do sprawozdań finansowych za znaczne szeregi czasowe obejmujące okres przedemisyjny.

${ }_{26}^{26}$ M. L. DeFond, J. Jiambalvo, Debt covenant violation and manipulation of accruals, „Journal of Accounting and Economics" 17(1), 1994, s. 145-176.

${ }^{27}$ K. R. Subramanyam, The pricing of discretionary accruals, „Journal of Accounting and Economics" 22(1), 1996, s. 249-281.

${ }^{28}$ L. L. DuCharme, P. H. Malatesta, S. E. Sefcik, op. cit., s. 369-396. 


\section{Tabela 5}

Nietypowe przesunięcia międzyokresowe według modelu DeAngelo

\begin{tabular}{|l|c|c|c|c|c|c|c|}
\hline & Y-2 & Y-1 & Y0 & Y+1 & Y+2 & Y+3 & Y+4 \\
\hline Średnia & $-0,0020$ & 0,0230 & 0,0700 & $-0,1240$ & $-0,0030$ & $-0,0120$ & 0,0270 \\
\hline Mediana & 0,0050 & 0,0110 & 0,0640 & $-0,0810$ & $-0,0210$ & $-0,0070$ & 0,0190 \\
\hline $\boldsymbol{p}$-value & 0,9111 & 0,0907 & 0,0000 & 0,0000 & 0,7830 & 0,2783 & 0,0085 \\
\hline$(t$-Student) & & $*$ & $* * *$ & $* * *$ & & & $* * *$ \\
\hline $\boldsymbol{p}$-value & 0,8569 & 0,2191 & 0,0000 & 0,0000 & 0,2687 & 0,2810 & 0,0282 \\
\hline (Wilcoxon) & & & $* * *$ & $* * *$ & & & $* *$ \\
\hline Odch. stand. & 0,1650 & 0,1890 & 0,2320 & 0,2860 & 0,1940 & 0,1750 & 0,1520 \\
\hline Skośność & 0,2200 & 0,3000 & 0,1300 & $-0,5200$ & 0,3600 & $-0,0700$ & 0,1600 \\
\hline Kurtoza & 0,0600 & 0,2700 & $-0,0400$ & 0,4700 & 0,2500 & $-0,0200$ & 0,0000 \\
\hline $\boldsymbol{p}$-value & 0,4418 & 0,0036 & 0,0760 & 0,0001 & 0,0006 & 0,0318 & 0,0236 \\
\hline (Shapiro-Wilk) & & $* * *$ & $*$ & $* * *$ & $* * *$ & $* *$ & $* *$ \\
\hline N & 82 & 192 & 214 & 268 & 262 & 253 & 223 \\
\hline
\end{tabular}

Uwagi: Istotność statystyczna na poziomie $1 \%\left(^{*}\right), 5 \%\left({ }^{* *}\right), 10 \%\left({ }^{* * *}\right)$.

Źródło: opracowanie własne.

\section{Tabela 6}

Nietypowe przesunięcia międzyokresowe według modelu Jones

\begin{tabular}{|c|c|c|c|c|c|c|c|}
\hline & $Y-2$ & $Y-1$ & Y0 & $Y+1$ & $Y+2$ & $Y+3$ & $Y=4$ \\
\hline \multicolumn{8}{|c|}{ Panel A: Model Jones w wersji podstawowej } \\
\hline Średnia & $-0,0770$ & $-0,0490$ & 0,0500 & $-0,0220$ & $-0,0160$ & $-0,0210$ & $-0,0080$ \\
\hline Mediana & $-0,0360$ & $-0,0170$ & 0,0480 & $-0,0160$ & $-0,0210$ & $-0,0220$ & $-0,0070$ \\
\hline$p$-value & 0,0000 & 0,0004 & 0,0004 & 0,0127 & 0,0582 & 0,0067 & 0,2247 \\
\hline$(t$-Student) & $* * *$ & $* * *$ & $* * *$ & $* *$ & * & $* * *$ & \\
\hline$p$-value & 0,0000 & 0,0020 & 0,0002 & 0,0257 & 0,0196 & 0,0159 & 0,1660 \\
\hline (Wilcoxon) & $* * *$ & $* * *$ & $* * *$ & $* *$ & $* *$ & $* *$ & \\
\hline Odch. stand. & 0,2060 & 0,1930 & 0,2120 & 0,1410 & 0,1360 & 0,1150 & 0,0930 \\
\hline Skośność & $-0,5700$ & $-0,2200$ & $-0,1000$ & $-0,1400$ & 0,2300 & $-0,2000$ & 0,1200 \\
\hline Kurtoza & 0,3500 & 0,3500 & 0,3100 & 0,1700 & 0,0700 & 0,0500 & 0,4900 \\
\hline$p$-value & 0,0001 & 0,0166 & 0,2473 & 0,0215 & 0,0227 & 0,1614 & 0,0990 \\
\hline (Shapiro-Wilk) & $* * *$ & $* *$ & & $* *$ & $* *$ & & * \\
\hline $\mathbf{N}$ & 169 & 196 & 232 & 255 & 255 & 234 & 204 \\
\hline \multicolumn{8}{|c|}{ Panel B: Model Jones w wersji zmodyfikowanej } \\
\hline Średnia & $-0,068$ & $-0,033$ & 0,047 & $-0,017$ & $-0,017$ & $-0,019$ & $-0,011$ \\
\hline Mediana & $-0,028$ & $-0,017$ & 0,042 & $-0,013$ & $-0,027$ & $-0,020$ & $-0,010$ \\
\hline
\end{tabular}




\begin{tabular}{|l|c|c|c|c|c|c|c|}
\hline $\boldsymbol{p}$-value & 0,0001 & 0,0224 & 0,0014 & 0,0498 & 0,0425 & 0,0134 & 0,0970 \\
\hline$(t$-Student) & $* * *$ & $* *$ & $* * *$ & $* *$ & $* *$ & $* *$ & $*$ \\
\hline $\boldsymbol{p}$-value & 0,0011 & 0,0292 & 0,0003 & 0,0624 & 0,0122 & 0,0216 & 0,0593 \\
\hline (Wilcoxon) & $* * *$ & $* *$ & $* * *$ & $*$ & $* *$ & $* *$ & $*$ \\
\hline Odch. stand. & 0,2190 & 0,1980 & 0,2200 & 0,1380 & 0,1290 & 0,1150 & 0,0950 \\
\hline Skośność & $-0,5200$ & $-0,0300$ & $-0,1700$ & $-0,0300$ & 0,2700 & $-0,0800$ & 0,0800 \\
\hline Kurtoza & 0,3300 & 0,2100 & 0,5100 & 0,2200 & 0,0100 & 0,1100 & 0,4600 \\
\hline $\boldsymbol{p}$-value & 0,0008 & 0,0573 & 0,0253 & 0,0891 & 0,0412 & 0,1390 & 0,1293 \\
\hline (Shapiro-Wilk) & $* * *$ & $*$ & $* *$ & $*$ & $* *$ & & 203 \\
\hline N & 166 & 191 & 226 & 246 & 248 & 232 & 203 \\
\hline
\end{tabular}

Uwagi: Istotność statystyczna na poziomie 1\% $\left(^{* * *}\right), 5 \%\left({ }^{* *}\right), 10 \%\left(^{*}\right)$.

Źródło: opracowanie własne.

\section{PODSUMOWANIE}

Badania prowadzone były dla spółek z sektora pozafinansowego dokonujących pierwszych publicznych ofert na rynku głównym Giełdy Papierów Wartościowych w Warszawie w latach 1998-2013. Celem była odpowiedź na pytanie, czy dla spółek dokonujących pierwotnych emisji akcji w Polsce zaobserwować można zjawisko zarządzania zyskami w okresach okołoemisyjnych.

W procesie empirycznej identyfikacji zjawiska manipulowania zyskami zastosowane zostało podejście zmierzające do wykrycia zarządzania wynikami poprzez działania o charakterze memoriałowym. Badania empiryczne dotyczyły czterech grup problemów badawczych: skłonności do przekraczania zysku zerowego, skłonności do przekraczania rentowności roku poprzedniego, manipulowania zyskami przez dokonywanie nietypowych przesunięć międzyokresowych oraz konsekwencji manipulowania zyskami dla kolejnych okresów sprawozdawczych.

Wyniki badań wskazuja, że w roku debiutu liczba firm wykazujących małe zyski $\mathrm{w}$ relacji do firm raportujących małe straty była relatywnie wysoka. W latach poemisyjnych (szczególnie w roku bezpośrednio po debiucie) następował silny spadek wartości wskaźnika odnoszącego liczbę spółek raportujących małe zyski w relacji do tych odnotowujących małe straty.

W roku IPO zaobserwowano nasilenie skłonności do przekraczania wartości progowej w postaci zysku i rentowności sprzedaży na poziomie roku poprzedniego. Kosztem takich okresowych przesunięć dokonywanych w roku wejścia na giełdę lub przed debiutem, w kolejnych latach spółki odnotowywały relatywne spadki rentowności. Dla spółek dokonujących działań z zakresu zawyżania zysku w roku debiutu zaobserwowano relatywny spadek rentowności w roku kolejnym również przy zastosowaniu metody Degeorge i in.

Na podstawie modelu DeAngelo, modelu Jones w wersji podstawowej oraz zmodyfikowanej wykazano istotne statystycznie nietypowe przesunięcia mię- 
dzyokresowe na poziomie świadczącym o zjawisku zawyżania wyniku finansowego w okresie emisyjnym. W roku następującym po debiucie odnotowano silny, statystycznie istotny spadek przeciętnego poziomu nietypowych korekt. Wyniki badań przeprowadzonych dla spółek z sektora pozafinansowego dokonujących pierwotnych emisji akcji na GPW w Warszawie wskazuja, że debiutujące spółki - przez działania typu memoriałowego - dążyły do zwiększenia wyniku finansowego w okresie wejścia na giełdę.

Uzyskane rezultaty badań empirycznych nad zjawiskiem zarządzania wynikiem dla spółek dokonujących IPO w Polsce nie wyczerpują dyskusji w tym obszarze. W kolejnych pracach badawczych rozszerzeniu ulec może zakres modeli pozwalających na wyróżnienie typowych i nietypowych przesunięć międzyokresowych. Na uwagę zasługuje również niedostatek badań nad zjawiskiem manipulowania zyskami dla polskiego rynku kapitałowego dla innych zdarzeń niż pierwotne emisje akcji. Ciekawym kierunkiem badań będzie także ocena skłonności do przekraczania wartości progowych w postaci prognozowanych zysków oraz zbadanie związku pomiędzy skalą manipulowania zyskami w okresie okołoemisyjnym a zjawiskiem krótkookresowego underpricingu i długookresowego underperformance.

dr Joanna Lizińska

Uniwersytet Ekonomiczny w Poznaniu

joanna.lizinska@ue.poznan.pl

dr Leszek Czapiewski

Uniwersytet Ekonomiczny w Poznaniu

leszek.czapiewski@ue.poznan.pl

\section{IPO FIRMS' EARNINGS MANIPULATION \\ ON THE WARSAW STOCK EXCHANGE}

\section{Summary}

The research sample covers non-financial initial public offerings (IPOs) on the Warsaw Stock Exchange (WSE, GPW) in the period 1998-2013. The study aims to answer the question whether Polish IPO firms managed their earnings in the issuance period.

Differentiated estimation models were applied and several approaches were engaged to detect accrual-based earnings management. The empirical research covered four groups of research problems: zero-profit threshold, last-year threshold, discretionary accruals and profitability consequences for the consecutive years.

High, positive and statistically significant discretionary accruals were reported in the IPO year or before going public, along with an inclination to report a positive and higher profitability. In consequence, the deterioration in profitability was observed in the following years. 